This is an electronic reprint of the original article. This reprint may differ from the original in pagination and typographic detail.

Author(s): Heikkinen, Hannu L.T.; Jong, Frank P. C. M. de; Vanderlinde, Ruben

Title: What is (good) practitioner research?

Year: $\quad 2016$

Version:

Please cite the original version:

Heikkinen, H. L., Jong, F. P. C. M. D., \& Vanderlinde, R. (2016). What is (good) practitioner research?. Vocations and Learning, 9(1), 1-19.

https://doi.org/10.1007/s12186-016-9153-8

All material supplied via JYX is protected by copyright and other intellectual property rights, and duplication or sale of all or part of any of the repository collections is not permitted, except that material may be duplicated by you for your research use or educational purposes in electronic or print form. You must obtain permission for any other use. Electronic or print copies may not be offered, whether for sale or otherwise to anyone who is not an authorised user. 


\section{What is (good) practitioner research?}

\section{Reflections on the special issue: 'Improving professional}

practice and competencies within practice-based research'

This special issue recognizes EAPRIL (The European Association for Practitioner Research on Improving Learning) as a platform for practitioner and practice-based research through the $10^{\text {th }}$ annual conference for practitioner research on improving learning in education and professional practice. EAPRIL is initiated ten years ago by the well-known 'European Association for Research on Learning and Instruction' (EARLI). EARLI wanted to support practitioner research by a platform where practitioner researchers and researcher doing practice based research can meet each other and exchange research results and experience in a highly interactive way. Nowadays, EAPRIL and EARLI collaborate as independent research associations. EAPRIL research conference presentations reflect papers like in this special issue; recent foci on practice-based research that elaborate ways, in which this form of inquiry can be used and implemented to support learning for and throughout lengthening working lives, for all categories of workers and occupations (EAPRIL conference proceedings, 2014, 2015). The context, in which these manuscripts were collected provides a special view on the world of vocational learning - that of practice-based research or practitioner research. It could be said that the EAPRIL organisation itself is deeply rooted in practitioner research, as its abbreviation stands for: European Association for Practitioner Research on Improving Learning (in Education and Professional Practice). The keywords 'practitioner' and 'research' indicate the core common aims and passions of all those committed to EAPRIL, and also of the authors of this special issue. Hence, the emphasis is on research, which is done by practitioners, for practitioners, and through interaction and collaboration between practitioners. In this special issue, versatile examples of studies inspired by this kind of research can be found. The idea of practitioner research and its focus within the EAPRIL organisation is situated within a broader context of knowledge 
production, dissemination and use in educational research (Vanderlinde and Van Braak 2010).

As an initial consideration, what exactly is practitioner research? And, more importantly, what makes good practitioner research? These questions are not easy to answer and researchers use different concepts of practitioner research in association with different ideas on the nature of 'good' practitioner research. The questions have often been posed in several EAPRIL conferences (e.g. Ros and Vermeulen, 2010; Bakx, A., Heeffer, \& De Koster, 2011; De Jong, Beus, Richardson and Ruijters 2013; Heikkinen 2014); and outside EAPRIL over the years (e.g. Murray, 1992; Lewin, 1993; Lane \& Corrie, 2007; Enthoven \& de Bruijn, 2010; Schaenen, Kohnen, Flinn, Saul, \& Zeni, 2012; Shaw \& Lunt, 2012; Striker, 2002). At first glance, practitioner research would appear to refer to something like workplace research or development work within a professional field that is carried out by practitioners, who are personally involved with the professional practices, actions and activities of the field. This brings practitioner research close to the lifelong and 'life-wide' processes of professional learning that involve inquiry into the methods, systems, programs, and policies of professional practices. Not surprisingly, practitioner research seems to be a popular approach in vocational teacher education and in universities of applied sciences. Therefore, it is natural that these institutions have also been strongly represented in the EAPRIL organisation and in its annual conferences.

To what extent does EAPRIL reflect the achievement of a collective identity for researchers, who are interested in practical development work in vocational learning 'without an extra burden of theory'? From this perspective, practitioner research may be studied as an interesting example of a tribe, in accordance with the classic book: "Academic tribes and territories" by Becher and Trowler (2001). In academic territories, practices are shaped, so that specific 'tribal' characteristics are discernible within disciplines. An important element of a tribe is the sense of community and togetherness offered by the social community. Have practitioner researchers - like representatives of some other research approaches or methodologies - accidentally or purposefully founded an alternative 'academic' tribe? Sometimes, this tribe actually seems to gather somewhere outside of the academic terrain, or at least somewhere on the borderline between 'academics' and 'practitioners' (Anderson and Herr 1999). 
Literature reviews (Broekkamp \& van Hout-Wolters, 2007; Heikkinen 2014; Vanderlinde and van Braak 2010) actually reveals that there is no perfect consensus of the meaning of the term 'practitioner research', but various approaches can be found under this umbrella. At a general level, practitioner research can be defined as: "the intentional and systematic inquiry into one's own practice”, (Dinkelman 2003, p. 8), and it focuses on both the development of local knowledge (i.e. improvement of the teaching and learning practice) and public knowledge (i.e. academic knowledge generation). Hence, practitioner research does not resemble a 'tribe', but can be thought of as a type of 'service station', at which researchers working for developing professional practices 'fill their tanks with fuel'. There are rather different expressions to conceptualise this family of research, including: practice-oriented research; practice-as-research; practice-based research; practice-led research; mixed-mode research practice; and practice through research (Candy 2006; Campbell 2007). In addition, traditional design research (Van den Akker, Gravemeijer, McKenney and Nieveen 2006), ecological transdisciplinary inspired research (ETI); De Jong et al. 013), applied research and action research (Carr 2005; Campbell 2007), are often located under the 'big umbrella' of practitioner research. However, all of these approaches carry special connotations, and there are also some clear differences between them. For example, some authors postulate that practitioners are in charge of practitioner research (Campbell 2007), whereas others concede that practitioner research might also be done by full-time academics (Marshall 2010). The realm of art, craft and design is sometimes emphasised as the main context (Candy 2006), whilst some others say that practitioner research is typically undertaken in the fields of education and in social- and health care (Campbell 2007). Sometimes practitioners are encouraged to become better 'consumers' of research reports (Marshall 2010), whereas others emphasise the strong autonomous agency of the practitioners in the production of knowledge and speak about a 'research journey' (Loughran 2014), or about empowering and developing wisdom in the practice by co-creation (De Jong et al. 2013). The role of the practitioner agency in the production of knowledge is especially emphasised in the tradition of critical and participatory action research (Carr and Kemmis 2002; Kemmis and McTaggart 2000).

An even more problematic question to answer is how to judge: What is a 'good' piece of practitioner research and what is 'less good'? Over the tradition of empirical inquiry, this question has usually been approached through the concepts of 'validity' and 'reliability' of research results which have even been regarded as the cornerstones of scientific inquiry. Some practitioner researchers still prefer to apply these traditional concepts whereas some 
researchers tend to avoid these terms or substitute them with other expressions (Niglas 2004, 12-13). One of the main reasons to avoid the terms of validity and reliability is the fact that the meaning of the concepts has undergone a number of transformations and revisions in the era of qualitative inquiry.

Originally, the concept of validity refers to how well a test measures what it is purported to measure (Phillips, 2014). The concept is usually split in internal validity “(...) the basic minimum without which any experiment is uninterpretable e.g. did the experimental treatments makes a difference in this specific experimental instance?"(p. 5); “(...) the factors that directly affect measurements" (p16); and external validity which concerns generalizability "to what populations, settings, treatment variables and measurements can this effect generalized?”(p. 5); “(...) potential specificity of the effects X to some undesirably limited set of conditions” (p17) (Campbell and Stanley, 1963). According to Shadish, Cook and Campbell (2002) validity can be seen as the as "the approximate truth of an inference" (p. 475). "Validity is not a property of methods but of inferences and knowledge claim” (p.480). The critical question for practitioner research is: Do practitioner researchers typically use some (numerical) measurements, or do they rather seek to provide evidence in some alternative ways? Nowadays, it seems that qualitative approaches have won popularity among practitioner researchers. In qualitative research, the aim is not to measure the reality but to interpret it; qualitative researchers effort to understand the phenomena in a holistic way by using various sources for evidence, such as interviews or authentic perceptions which are not necessarily transformed in the form of numerical data. The concept of reliability means that the research results should be something more general than a just one finding in one special historical moment. The results should be repeatable so that other researchers would be able to perform similar experiments and introduce exactly same results, under the same conditions. Without the replication of (statistically significant) results, the study does not fulfil the requirements of testability. Practitioner research, however, is not typically done under conditions that could be standardized. On the contrary, it is actualized under unique social conditions at work and in everyday life in social practices that are not replicable. This makes the concept of reliability practically useless in the context of practitioner research, and even somewhat absurd in its original meaning. (Angen 2000; Heikkinen, Huttunen and Syrjälä 2007; Niglas 2004). 
One way to solve the problems about the applicability of the concepts of validity and reliability is to revise their meaning so that they fit better to the conditions of practitioner research. Another way to solve the problem to seek for alternative 'indicators', 'criteria', 'standards' or 'quality principles' for practitioner research (Furlong, 2005).

Given the different interpretations of practitioner research and the problems of judging its 'goodness', one of the aims of this introduction article is to study the map of practitioner research and to reflect its epistemological roots, even going back to Aristotle's philosophy about different forms of 'knowing'. Its main aim is not, however, to offer an allencompassing review of all the possible interpretations of practitioner research, but is instead to clarify its epistemological basis. To establish what kind of knowledge is obtained through practitioner research, what purpose does it serve, and how do these approaches differ from other kinds of inquiry?

When unpacking the concept into pieces, two main ingredients were initially found: practitioner and research. The word 'research' has often been taken for granted, but to understand what practitioner research actually is, it is useful to further investigate its origins. The word 'research' comes from 'Old French'. It consists of an intensive prefix; 're_', and a verb; 'cercher'. In Old French, and originally in Latin, the prefix re-refers to: 'going back to the original place; or doing something once more', also with a sense of 'undoing'. The Old French verb 'cercher' means 'to seek for' or 'to search for'. Literally, the word research means to search again. According to Harper (2015), the meaning of research as scientific inquiry was first attested to in the 1630's. The word 'practitioner' is a hybrid formed from the Old French word 'practitian', which means 'parishioner'. Hence, a practitioner is someone who belongs to a community of other practitioners, like a parishioner belongs to a parish. The word practitioner comes directly from the noun 'practice', which in Old French means to 'follow or employ; to carry on a profession,' especially in medicine, and from the Medieval Latin word 'practicare': 'to do, perform, practice'. Thus, this approach must have something to do with research about (social) practices, e.g. human engagement in (purposeful) actions. In other words, practitioner research may be understood as finding new knowledge about 'performing, doing', e.g. practices. This interpretation brings the approach close to practice theories (Nicolini 2013) and praxeology (Röling and De Jong 1998; Long 2015). From this perspective, the focus is on what constitutes social practices, how they are 
unfolded and prefigured (enabled and constrained) on the social site where the practices happen (Kemmis and Smith 2008; Kemmis and Grootenboer 2008; Nicolini 2013).

The relation between the two key words 'research' and 'practice' may be studied from a couple of alternative perspectives by changing the preposition between the words. Instead of doing research about practice or on practice, a view that emphasises doing research for practice with practitioners may be adopted; that is, improving social practices by doing research together with the persons involved in the practices. Research for practice takes place often through a dialogical relationship between researchers and practitioners. Sometimes practitioner research is performed by the practitioners themselves, without academic researchers. In this kind of orientation, the practitioners and practices are not observed by outside spectators. As crystallised by Deborah Cameron and her colleagues (1994, p. 22): "persons are not objects and should not be treated as objects". This orientation to practitioner research is typical for critical emancipatory action research, as well as other forms of 'empowering research' (Carr and Kemmis 1985; Cameron et al. 1994).

Practitioner research is most often performed to solve practical problems or to contribute to the progression of practice in order to improve the quality of the practitioner-researcher's practice (Fox, Martin and Green 2007). From this point of view, practitioner research may be understood as a lifelong journey of professional development that not only takes place in formal settings, such as schools and universities, but particularly in informal and nonformal settings. This view on practitioner research is clearly presented in this issue in the article by Arnoud Hulsbos, Arnoud Evers and Joseph Kessels. They introduce workplace learning activities of school leaders to illustrate how school leaders learn in the workplace, and to demonstrate which work-related questions drive learning and what outcomes they achieve through workplace learning. The article by (Vanderlinde et al.) in this volume also draws on the perspective of professional learning at work: it introduces an interesting view on professional development of teacher educators. The article offers a perspective to teacher educators as second-order practitioners, and the article is inspired by the aim to develop a 'researcher disposition' for teacher educators; in other words, a hybrid role as a teacher educator-researcher.

In contemporary literature about professional development, the impact of the working society has been emphasised. Professional learning does not take place in a vacuum but is essentially a social phenomenon. This is why Professional Learning Communities (PLCs) have been 
often focused on in research literature. A good example of this approach in this volume is the article by Martijn Willemse, Fer Boei and Marieke Pillen, which introduces a community of inquiry, in which teacher educators conducted a collaborative research on their practices, so as to examine their professional development and to identify how such a collaborative community is enabled.

The approach, which focuses on developing professional practices instead of just studying them, is manifested in various traditions such as action research in its various forms (Burns 2007; Carr and Kemmis 2002; Reason and Bradbury 2007), different versions of design research (Van den Akker, Gravemeijer, McKenney and Nieveen 2006), and the developmental work research approach, which was inspired by the socio-cultural activity theory (Engeström 2005), to mention a few. The development of professional practices in relation to learning and working is the subject of the contribution of Ilya Zitter, Emee Hoeve and Elly DeBruijn, who researched the design of learning environments on the intersection of school and work. Through a cross-boundary approach and an analytical model with two dimensions ('acquisition - participation' and 'constructed - realistic'), they identified how professional practice can be developed in different possible learning environments. A close connection can also be seen between practitioner research and case study methodology in fields, such as anthropology, medicine, psychology, political science, sociology, management, coaching, education, public administration and human services, that emphasises local and contextual knowledge instead of universal and general knowledge, which has provided the ideal in the dominating research paradigm (Marshall 2010).

Not unnaturally, the umbrella of the practitioner research approach has also been called 'practice-based research' as a synonym for practitioner research. However, the concept of practice-based research seems to have different meanings for different people. The concept has been used in a special way in the field of art, crafts and design. In that area, practicebased research refers to an investigation undertaken in order to gain new knowledge by presenting creative outcomes of art and craft practices that are often conceptual artefacts, such as images, music, designs, models and digital media, or other outcomes, such as performances and exhibitions (Bereiter 2002; Popper 1963; De Jong 2006). However, the significance and context of the products are described verbally (Candy 2006.) 
Another related approach is 'practice-led research', which is an approach closer to the traditional research methodologies, since the emphasis is on obtaining knowledge about practices with a clear intention to improve them, rather than creating and reflecting on artefacts. Hence, the results of practice-led research may be fully described in text form without the inclusion of a creative outcome. Such research includes professional practice as an integral part of the research project, and often falls within the general area of action research (Candy 2006.)

An important concept strongly connected with practitioner research is that of praxis. This approach has been introduced clearly in this special issue in the contribution of Alfred Weinberger, Jean-Luc Patry and Sieglinde Weyringer, despite the fact they do not explicitly use the concept of praxis. This understanding of practitioner research emphasises the aspects of ethical and moral thinking and decision-making in research, which means that research cannot be a value-free investigation of the facts outside of the researcher, but involves normative elements. From this point of view, research and theory must be committed to a political and ethical engagement with practice (Marshall 2010). At the most extreme end, practitioner research can be understood as 'research for praxis', a morally informed and committed action of the individual practitioners (in the Aristotelian sense of praxis), who make history through shaping social formations and conditions for collectivities of people (in the post-Marxian sense of praxis; Kemmis 2010).

Many authors emphasise that research on practice and for practice cannot be performed from an 'outsider position', but that the researcher must be involved in the practices themselves in order to understand them from an 'insider position' (Anderson and Herr 1999). Reality cannot be understood without interacting with that reality (Naess et al. 1956). Reality is always on the move. Dividing it into objects, facts and propositions is artificial, building blocks for constructing a human-made worldview. Reality might be more a dynamic, constant change of connections. Entities can be seen as just temporary connections, expressions of reciprocal dependency (De Jong et al. 2013). This attitude challenges the quest for an objective standpoint, which has been emphasised in the (post)-positivist research paradigm aimed at general and objective knowledge that is applicable regardless of the actual material, historical or social context or the personal experiences of the knowledge gatherer. This change can be understood as a paradigm shift from positivism through post-positivism into critical theories, constructivism and postmodernism (Denzin and Lincoln 2005; Niglas 2004). 
Post-modern and post-structuralist theories have challenged the detached observer role in research, thus, opening doors for practitioner studies that involve everyday problems and relationships (Marshall 2010). For Denzin and Lincoln (2005), the most relevant aspect of the latest turn within the qualitative research paradigm is to become even more conscious of the political-, moral- and ethical aspects of research. This challenges the traditional distinction between facts and values in the Western tradition of thinking. That is why the origins of this tradition must be examined more closely. The notions of theory and practice are rooted in the philosophy of ancient Greece. The impact of Aristotle has been particularly influential. Therefore, it is necessary to study the Aristotelian notion of knowledge forms in order to understand what practitioner research essentially is, how it differs from the dominant modernist paradigm and how to judge what is good practitioner research.

\section{Forms of knowledge in practitioner research}

Aristotle's interpretation of different knowledge forms has been influential throughout the Western tradition of philosophy. It actually provides the basis of contemporary understanding of knowledge and, thus, determines understanding of scientific research. Therefore, so as to better understand the relationship between practitioner research and other kinds of knowledge production, the forms of knowledge that Aristotle introduced in his Nicomachean Ethics must be explored.

Aristotle discussed three forms of knowledge: one theoretical, called episteme; and two practical forms of knowledge: called techne and phronesis (Saugstad 2005). Each of these knowledge forms are actualised through specific activity forms (episteme -> theoria; techne $=>$ poiesis; phronesis $=>$ praxis). The knowledge forms and activity forms with their specific purposes are illustrated in Table 1.

Insert Table 1 about here

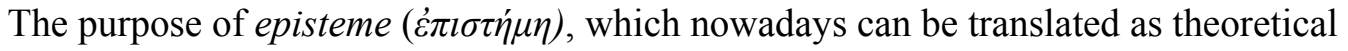
knowledge, was to give a perspective on everything in the world from the outside, originally from the perspective of gods who, according to the mythology, lived on the Olympus 
Mountain above mortal humans and had a view on everything happening in the Cosmos. Episteme, in other words, is the human's attempt to raise their perspective to that of gods. The word 'episteme' is also the origin of the word epistemology, which is now known as a branch of philosophy concerned with the nature and scope of knowledge. The activity form based on episteme is theoria ( $\theta \varepsilon \omega \rho i ́ \alpha)$, which means to observe the whole world from the outside. Literally theoria means 'looking at', 'gazing at', or 'being aware of'. Theoria has no practical aims or purposes; this activity form was originally actually just about contemplation of the cosmos without any external ends, and it serves as an end in itself. The interest of this kind of activity is just to trace the general, eternal and regular aspects of the world and life. (Aristotle 1994; Carr 2006 and 2007; Kemmis 2010; Saugstad 2005.)

This understanding of knowledge has been emphasised in the Western tradition of scientific research. The origin of the word 'episteme' also explains the reason why scientific research is said to aspire to a 'god's-eye-view' on reality. Given the 'god-like' perspective from above, Saugstad (2005) calls this form of knowledge 'spectator knowledge' (see table 2). It is an activity, in which the human looks or gazes at something as a spectator. In this case, the spectator (researcher) is clearly an 'outsider', not an 'insider'.

Table 2 about here

For practitioner research, the more interesting form of knowledge is practical knowledge which is, in contrast to the 'divine view of gods', something typical for mortal humans who see the world from a perspective of life lived through their own experience. Saugstad (2005) calls this kind of knowledge 'participant knowledge', but in the context of this article it could be called 'practitioner knowledge'. The purpose of practical knowledge is to enable and foster a human's ability to produce material products (in the physical-material realm) and to act in the world in a meaningful way with other humans (in the social realm). The first of these practical knowledge forms that aims at honing skills and capacities to produce products

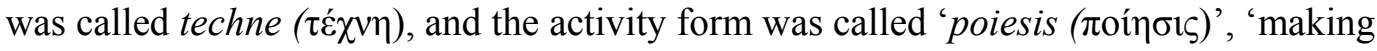

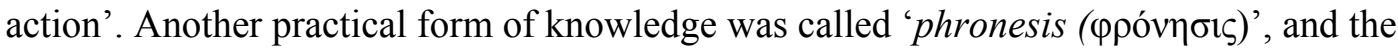
activity form (what people do) was called 'praxis $(\pi \rho \tilde{\alpha} \xi 1 \zeta)$ ', which has sometimes been translated as practical wisdom or practical intelligence (Sternberg 1985). The aim of praxis 
was to live a good life; thus praxis had an end in itself, whereas poiesis always had an external end of the action, namely the product which is produced through the action; the process of making products. In both cases, the knowledge subject (the 'researcher') is not an outsider of the practice, but an 'insider' who is personally involved in the practice.

In this way, poiesis is instrumental action as the goal lies outside of the activity. Theoria and praxis, in contrast, are action forms with ends in themselves; in other words, they are both non-instrumental types of action. Theoria represents pure theoretical interest; it is all about human (or, originally, divine) curiosity about the world or the Cosmos.

How can one judge if one has mastered these different realms of knowledge? The judgment of good techne, to start with, is based on an evaluation of the quality (usability or usefulness) of the product that is produced through poiesis. Good poiesis is actualised in good pottery, safe aircrafts, environmentally-friendly cars, intuitive user interfaces of mobile phones, and other mechanical- and technical innovations around us. There is no doubt that there are many examples of good poiesis around us. However, there are also a lot of examples of bad poiesis. In the course of modernity, humans have assumed that Nature is an unlimited resource of materials and energy without concern for the limitations of the ecosystem. Nature has been regarded as something inferior and subordinate to humans. In recent years, however, there is a growing awareness about human-life as part of the ecosystem (De Jong 2015), Therefore, Nature cannot be just seized and exploited. Humans must find a way of living in balance and dialogue with it.

The criteria for good theoria appear to be more problematic. Theoria, in its pure meaning, is not a product, but a process. It is an activity form that has no aims or purposes outside of the realm of theoria itself. In the modern world of scientific research, however, the results of research are increasingly evaluated in the light of products. Research is evaluated through articles, books, publication lists and other entities that clearly represent something outside of theoria. These products, somehow, seem to represent poiesis more than theoria. This way, it may be claimed that theoria in its original meaning does not seem to be always at the core of research. It might be considered if neo-liberal notions of research groups like research centers, universities, including universities of applied sciences, have become units of production like factories, rather than havens of free- and critical thinking and human contemplation? 
Good praxis is human action which forms an aim in itself. Judgment of good praxis can be put in the form of a question: 'Are you able to live a good (and virtuous) human life in harmony with other humans and the world around you?' The form of knowledge (phronesis) that enables good praxis is attached to an ethical- and social life that is entirely based on personal life experience accumulated throughout life as part of a society, culture and nature.

The Western research tradition of focusing on theoretical knowledge - something atemporal, universal, certain, eternal, general and abstract in nature - reached its ultimate form in positivism and post-positivism (Carr and Kemmis 1985; Anderson and Herr 1999). It formed a good pair with techne, and the cultivation of these two knowledge forms throughout the modernisation of the enlightened Western world achieved a scientific- and technical revolution. It might be questioned if the knowledge form of phronesis has been overshadowed by techne and theoria? However, in many professions, such as teaching, the judicial profession or social work, the accumulation of phronesis is essential. These professionals also need some theoria and techne, but the most essential knowledge in these professions is that of phronesis.

All the aforementioned knowledge forms have something to do with practitioner research. However, the two forms of knowledge that Saugstad calls 'participant knowledge', the knowledge forms of phronesis and techne, need some more attention in judging the quality of practitioner research. These realms of knowledge have also been taken into account in the proposal made by (Heikkinen, et a1.2007), in the Education Action Research Journal. Along with the turn to qualitative research methodology and postmodernism, Heikkinen and his colleagues studied dozens of new approaches and concepts for evaluating the 'goodness' of research. A number of advocates for qualitative research think that the concept of validity should be set aside, since it carries heavy connotations of the post-positivistic and statistical research paradigm (Angen 2000; Denzin and Lincoln 2005; Hatch and Wisniewski 1995). This is the reason why 'goodness' of practitioner research must be judged on its own terms. Hence, Heikkinen et al. (2007) suggested five principles for validation, not for validity, following the formulation introduced by Steiner Kvale (1996). The idea of validation refers to an endless process of meaning making and negotiation, whereas the concept of validity leans on correspondence between propositions and the facts in the outside world (Heikkinen, Huttunen \& Kakkori 2001). 
(1.) The principle of historical continuity means that the practitioner-researcher recognises the historical evolution of the professional practice. This kind of understanding requires the knowledge form of phronesis; the practitioner-researcher must be sensitive to the question of how the quality of human life has been promoted by the practice and the research? A virtuous practitioner-researcher is well-informed by the traditions of the field and the historical continuum of the practice development. The principle of historical continuity also involves emplotment: a good research report discovers the logical sequence of the events, which often is articulated in the form of a narrative. A good narrative reveals the causal relations underlying the story, which are considered important in the Galilean tradition, and it also perceives the intentionality and teleology of human actions, which represent the Aristotelian logic of action (Wright 1990). A person with capacities for phronesis understands human intentions and aspirations; the sense of history is achieved in the process of gaining practical wisdom in human-life and is accumulated through life-experience.

(2.) The principle of reflexivity is based on the idea that reflective / reflexive thinking is pivotal in practitioner research, which also necessitates practical wisdom (phronesis). Reflexivity requires a self-critical approach; the practitioner-researcher should be aware of how knowledge about practice is generated, and, furthermore, how relations of power operate in this process. The impacts of one's personal experiences whilst interacting with other participants of the practice should also be taken into account. Furthermore, this principle also includes analysis of ontological presumptions, i.e. presumptions concerning reality, and epistemological presumptions, which are not only about theoria in Aristotelian terms, but more broadly, about (social) construction of human practices (De Jong 2015). Reflexivity is also concerned with the role that emotion plays in social practices. (D’Cruz, Gillingham and Melendez 2007.)

(3.) The principle of dialectics is based on the idea that social reality is constructed as a dialectical, hermeneutic and collaborative process through interpersonal discussion. This also necessitates a sense of phronesis of the researcher. A practitioner-researcher, who respects this principle gives space to different voices and interpretations of the same events and gives space to the authentic voice of the participants to keep them as genuine and original as possible, so that the informants can recognise their own thinking in them, and are even involved in a co-creation of understanding/meaning (De Jong et al. 2013, 
2015). The principle of dialectics comes close to two of the classical validity principles for practitioner research introduced by Anderson and Herr (1999, p. 16), namely dialogic validity and democratic validity. In the same manner, the peer-review process is used to guarantee the quality of academic research, Anderson and Herr have suggested that we should promote democratic and dialogic validity by introducing peer-review amongst practitioner communities. In some versions of action research, labelled as critical-, emancipatory- or participatory action research, democratic validity is heavily underlined, even to the extent that it is considered that good practitioner research can only be done through democratic collaborative inquiry (Carr and Kemmis 1986).

(4.)The principle of workability can be crystallised in the words of Patton (2002, 578): "I can show you what is useful. What is useful is true." The formulation of the principle was influenced by the ideas of Greenwood and Levin (1998). This principle has much to do with techne, but the principle cannot be reduced to poietic action without residue. The principle of workability also means that attention must be paid to the social consequences and, thus, requires capacities for phronesis. Thus, the principle of workability involves an ethical attitude. The practical consequences of research on the study subjects and researchers, as well as the scientific community, society and humankind as a whole must be considered. From this point of view, ethically perfection and faultless must be prioritised, but research should enable an analytical approach to ethical questions and propose solutions to them. The principle of workability also involves a critical view of change. From this perspective, critical thinking should be learned, so as to recognise the ways, in which dominant ideologies and social structures work in coercion and oppression (Brown and Jones 2001). Sometimes, the main consequence might be a critical public discussion or debate on such issues as power, domination or coercive ideologies or social structures. Thus, the principle of workability is close to outcome validity and process validity, as introduced by Anderson and Herr (1999, p.16). For Anderson and Herr, outcome validity is synonymous with a 'successful' outcome of the project. Process validity, in turn, refers to the process of meaning making and reflection and questions to what extent problems are framed and solved in a manner that permits ongoing learning of the individual or the system. Thus, outcome validity is dependent on process validity, in that, if the process is superficial of flawed, the outcome will be similar. 
(5.)The principle of evocativeness means that research stimulates and provokes a person to think about things in a new and different way. This principle has similarities with Anderson's and Herr's (1999, p. 16) catalytic validity, which refers to: "the degree to which the research process reorients, focuses, and energizes participants toward knowing reality in order to transform it”, (Lather 1986, p.272, cited in Anderson and Herr 1999, p. 16). The evocativeness (or the catalytic force) of a research report is not only based on cognitive-rational thinking, but also touches the readers on an emotional level. This can be achieved in artistic- or narrative accounts (Zeller 1995; Campbell 2007). This type of quality principle is not actually supported by the Western traction of science, or by Aristotelian epistemology. Rationality is one of the key virtues of humans, and emotions are separated from the process of acquiring knowledge. In the times of Aristotle, it was assumed that humans differ from animals on the basis of this very feature: humans are essentially rational creatures, and to follow the virtue of humans, one should live a rational life and not a life guided by emotions and instincts. However, nowadays the research on learning shows that most significant learning experiences are both cognitive and affective in nature, which is why the principle of evocativeness is also relevant for judging knowledge construction. It may be claimed that knowledge about how to live a good human life - which is the ultimate aim of praxis - also includes the range of human feelings, emotions and the possibility to express ideas and thoughts through artistic expressions. Knowledge cannot be completely separated from the moral or ethical issues, and this applies especially to practitioner knowledge, which is often informed by phronesis. Nowadays, our relation to Nature, including the cultural- and social environment, is one of the most important moral- and ethical issues of practitioner research. As Plato (1925) described in his dialogue Menexenus: "All knowledge, when separated from justice and virtue, is seen to be cunning and not wisdom."

Artistic products may also be products of techne, but at its best, an artwork is something more than just a beautiful item or practical tool. If the promotion of practitioner research that enables us to live a good human life is an objective, it would be a mistake to detach the realm of emotions and expressions from the realm of rationality. This is why practitionerresearchers should be encouraged to apply evocative ways of representing their research. 
The issue of 'goodness' of practitioner research can be seen from different perspectives, and the aforementioned set of principles provide one possible angle. Sometimes, however, researchers seem to follow these kinds of principles implicitly and unconsciously. Whilst reading the manuscripts of this special issue, many of these principles have been detected as realised within the individual (practitioner) studies. For example, the study of Willemse et al. shows a clear sense of historical continuity; the historical awareness of 'communities of inquiry' (p. 1). The manuscript reveals how, on the basis of participant feedback, the communities evolved during the research. As participating educators worked in couples, their communicative space was created through a process (p. 3) of exchanging ideas, experiences and collaboration, which clearly represents the principle of dialectics. The authors seem also to highlight the principle of reflexivity (p. 2) by 'reflecting on the learning experience'. The principle of evocativity (p.5) can be seen in the way they involved participants to think about how community of inquiry contributed to their professional development and practice, such as supervising their student's research and their teaching practices. Not only the rational arguments, but also the beliefs and emotions shared language that developed through participating in the study.

The study of Vanderlinde et al. concerning the transformative development context of teacher educators in the disposition of practitioner (teacher) research(er) concerns a self-assessment instrument that supports the principle of reflexivity (p.2) in a more systematic way, taking into account cognitive-, affective- and behavioural dimensions. The delivery of a comprehensive feedback report to the participating teachers supports reflexivity, although it is a first, but marginal step. More evocative ways (p. 5) may be considered to present the reflexive insight in using the instrument to enhance the workability (p. 4) of it. In the construction of the instrument, different voices and interpretations of the praxis (p.3) are used by involving stakeholders e.g. researchers and teacher educators in evaluating the content validity and clarity.

The Weinberg et al. study shows the teacher educator as a research practitioner, extending to pre-service teachers in the 'Values and Knowledge Education' (VaKE) project. This study is clearly rooted in reflective thinking (p. 2). The principle of dialectics is highlighted (p. 3), as moral dilemmas enter the language of teacher educators and pre-service teachers. This 
section is also very evocative and has a strong catalytic power. Teacher educators as practitioner researchers were involved in selecting moral conflicts in the first phase, and by doing so, they were set in a reflexive action. The principle of workability is actualised (p. 4) in the third phase of their research, as the participants investigate the perceived learning climate during the intervention, the new teaching practice.

The study of Hulsbos et al. actually went into the depth of the praxis of school leaders and the voice of the praxis was mainly active through the interview that demonstrated a 'rich form of reflection for participating school leaders' (p. 2). The member check for approval of the data analysed by the respondents represents a way of realising the principle of dialectics (p3).

The study of Zitter et al. was focused on designing and improving the practices and, thus, was clearly motivated by the principle of workability. The researchers also used evocative methods (p. 5), such as photos of critical moments, presentations and workshops for peerdebriefing. This also promoted reflexivity of the participants (p. 2). These research activities go beyond a traditional member check. Together with 'thick descriptions', they contribute to the so-called 'trustworthiness' of the research e.g. the workability principle (p4). The 'trustworthiness' concerns the dialectics (p. 3), by alternation in the data analysis by frequent peer-briefings and member-checks. And also frequent discussions in the peer debriefing for critical reflection on the research activities and intermediary results. This approaches cocreation of interpretation of data and results. The reflexivity was performed with different practitioners, educational experts and educational researchers, but in particular, the three participating teachers. The rich descriptions supported the workability principle to enable improvement of the praxis, by judging how fitting and usable the results were (p. 4).

Looking at the research presented in this issue, it can be seen that researchers tacitly use the above described principles as part of their research, even though they do not mention the principles. This indicates that these principles are implicitly inherent in the ways, in which practitioners perform research and seek to ensure its quality. 


\section{Conclusion: Challenges for EAPRIL}

As Anderson and Herr (1999, p. 16) have stated: “any validity criteria for practitioner research are tentative and in flux". The intention is to encourage practitioner-researchers to reflect on the quality of their research in alternative epistemological ways that are rooted in the different forms of knowledge about practice. The main interest of practitioner research is not necessarily to produce knowledge ('theoria'), but first and foremost, to enable good (professional) work. Therefore, the classical forms of knowledge that have created the basis for the Western notion of scientific research must be referred to. This understanding emphasises the idea of seeing the world from an outsider's perspective (Aristotelian theoria) and ignores other kinds of knowledge. To understand the essence of practitioner research and to judge the quality of it, alternative views must be taken into account.

By stressing the different interpretations of practitioner research, and by providing a first map of practitioner research, it becomes apparent that all researchers and/or practitioners involved in this broad field are confronted with both conceptual- (e.g. 'what is practitioner research?' or 'what kind of knowledge is being developed?') and methodological- (e.g. 'what knowledge activities constitute practitioner research?') challenges. These challenges are of major importance to EAPRIL as a community and will guide EAPRIL for the next ten years, now that its tenth anniversary has been celebrated. Work must be done, by the practitioner research community in general, and EAPRIL in particular, on providing a more encompassing view of the different concepts of and approaches to practitioner research. Better knowledge on how these approaches differ from each other and what they have in common is required. More discussion about the nature of practitioner knowledge and the principles of quality of practitioner research is also needed. Our aim is not been to introduce a new set of criteria or another checklist that should replace a number of other checklists, to be ticked for (practitioner) researchers, but to introduce some alternative philosophical viewpoints to discuss research quality. As such, this special issue should appeal to practitioner researchers and the EAPRIL community to deeply reflect on the quality of their research in an epistemological way. The debate about the worthiness of practitioner research has been active for some decades, and more broadly, discussion about valid and reliable information and different forms of knowledge has been going on for centuries. Our intention is not to provide a final answer, but to continue the deliberation. We hope that our initiative 
will trigger further discussion, perhaps even some debate, on the fundamental question of: What is good practitioner research?

References:

Anderson, G.L., \& Herr, K. (1999). The new paradigm wars: Is there room for rigorous practitioner knowledge in schools and universities? Educational Researcher, 28, $12-21$.

Angen, M. (2000). Pearls, pith, and provocation. Evaluating Interpretive Inquiry: Reviewing the Validity Debate and Opening the Dialogue. Qualitative Health Research, $10(3), 378-395$.

Aristotle (1994). Nicomachean Ethics (Loeb Classical Library edition). Cambridge, MA: Harvard University Press.

Bakx, A., Heeffer, M., \& De Koster, C. (2011). Actieonderzoek als strategie voor personeelsbeleid in de basisschool: casestudy naar het hoe en wat van actieonderzoek in de praktijk. Nieuw Meesterschap, 2, 33-38.

Bereiter, C. (2002). Education and Mind in the Knowledge Age. Mahwah, New Jersey, London; Lawrence Erlbaum Associates, Publishers.

Becher, T., \& Trawler, P. R. (2001). Academic Tribes and Territories: Intellectual enquiry and the culture of disciplines. (Second edition, first published in 1989). Celtic Court: Open University Press.

Broekkamp, H., \& van Hout-Wolters, B. (2007). The gap between educational research and practice: A literature review, symposium, and questionnaire. Educational Research and Evaluation, 13(3), 203-220. http://doi.org/10.1080/13803610701626127

Burns, D. (2007). Systemic Action Research: A strategy for whole system change. Bristol: Policy Press.

Cameron, D., Frazer, E., Harvey, P., Rampton, M.B.H., \& Richardson K. (1994). The Relationship between researcher and researched: Ethics, advocacy and empowerment. In D. Graddol, J. Maybin \& B. Steirer (Ed.), Researching language and literacy in social context. London: Open University.

Campbell, A. (2007). Practitioner Research (pp. 18-25). London: TLRP. Online at http://www.tlrp.org/capacity/rm/wt/campbell (accessed 13 Jun 2015). 
Campbell, D.T., \& Stanley, J. C. (1963). Experimental and quasi-experimental designs for research. Chicago: Rand $\mathrm{M}^{\mathrm{c}}$ nally College Publishing Compagny.

Candy, L. (2006). Practice-based research. A guide. Sydney: University of Technology, Creativity \& Cognition Studios.

Carr, W. (2005). The Role of Theory in the Professional Development of and Educational Theorist. Pedagogy. Culture and Society, 13(3), 333-346.

Carr, W. (2006). Philosophy, Methodology and Action Research. Journal of Philosophy of Education, 40(4), 421-435.

Carr, W. (2007). Educational Research as Practical Science. International Journal of Research \& Method in Education, 30(3), 271-286.

Carr, W., \& Kemmis, S. (2002). Becoming Critical: Education Knowledge and Action

Research. (First published in 1986 by Deakin University Press). London:

RoutledgeFalmer.

De Jong, F. (2006). Doen, leren en kenniscreatie: Verstand en Competentie. [inaugural speech] Wageningen: Stoas Vilentum Hogeschool.

https://www.researchgate.net/publication/283149979_Doen_Leren_en_Kennisc reatie_Verstand_en_Competentie accessed November 2015. DOI:

10.13140/RG.2.1.2669.8961

De Jong, F., De Beus, M., Richardson, R., \& Ruijters M. (2013). Ecologically and Transdisciplinarily Inspired research: Starting Points for Practitioner Research and Sustainable Change, In: T. Zohar Harel (Guest Ed.) Special issue: Sustainability: Mulit-Disciplinary Perspectives. Journal of organisational transformation \& social change, 10, 163-17.

De Jong, F. (2015) Understanding the difference. Responsive education: a search for 'a difference which makes a difference' for transition, learning and education. Wageningen: Stoas Vilentum Hogeschool. https://www.researchgate.net/publication/283788931_Understanding_the_Diffe rence_Responsive_education_A_search_for_\%27difference_which_makes_the _difference\%27_for_transition_learning_and_education accessed December 2012. DOI: 10.13140/RG.2.1.3470.0562

Denzin, N. and Lincoln, S. (2005). (Eds.) The SAGE Handbook of Qualitative Research. Third Edition. London: SAGE. 
D’Cruz, H., Gillingham, P., \& Melendez, S. (2007). Reflexivity, its meanings and relevance for social work: A critical review of the literature. British Journal of Social Work, 37, 73-90.

Dinkelman, T. (2003). Self-study in teacher education: A means and end tool for promoting reflective practice. Journal of Teacher Education, 54(1), 6-18).

EAPRIL (2014). Conference proceedings 2014. Issue 1, March 2015, ISSN 2406-4653 https://eaprilconference.files.wordpress.com/2014/07/eapril-2014-proceedings _issn-aanvraag_defl.pdf accessed January 2016.

EAPRIL (2015). Conference proceedings 2015. Issue 2, (in print). https://eaprilconference.org/proceedings-2015/

Engeström, Y. (2005). Developmental Work Research: Expanding Activity Theory in Practice. Berlin: Lehmanns Media.

Enthoven, M., \& de Bruijn, E. (2010). Beyond locality: the creation of public practice based knowledge through practitioner research in professional learning communities and communities of practice. A review of three books on practitioner research and professional communities. Educational Action Research, 18(2), 289-298. http://doi.org/10.1080/09650791003741822.

Furlong, J., \& Oancea, A. (2005) 'Assessing Quality in Applied and Practice-Based Research in Education: a framework for discussion'. Review of Australian Research in Education No. 6: Counterpoints on the Quality and Impact of Educational Research.http://www.tlrp.org/capacity/rm/wt/campbell/docs/assessing_quality_sh ortreport_tcm6-8232.pdf. Accessed June 2015.

Fox, M. P., \& Green, G. (2007). Doing practitioner research. London: Sage.

Greenwood, M., \& Levin, M. (1998). Introduction to Action research. Social research for social change. London: SAGE.

Gadamer, H. G. (1975). Wahrheit und Methode. Wahrheit und Methode (4th ed.). Tübingen: J.C.B.Mohr (Paul Siebck).

Hatch, J.A., \& Wisniewski, R. (1995). (Eds.) Life History and Narrative. London: Falmer. Heikkinen, H. (2014). What is (Good) Practice-Based Research made of? Keynote address at the Annual Conference of the European Association for Practitioner Research on Improving Learning (EAPRIL), Cyprus, November 28 ${ }^{\text {th }}, 2014$.

Heikkinen, H., Huttunen, R., \& Syrjälä, L. (2007). Action Research as Narrative: Five Principles for Validation. Educational Action Research, 15(1), 5-19. 
Heikkinen, H., Huttunen, R., Syrjälä, L., \& Pesonen, J. (2012). Action Research and Narrative Inquiry: Five Principles for Validation revisited. Educational Action Research, 20(1), 5-22.

Heikkinen, H., Huttunen, R., \& Kakkori, L. (2001). This is my truth, tell me yours: Some aspects of action research quality in the light of truth theories. Educational Action Research, 9(1), 9-24.

Huttunen, R., \& Kakkori, L. (2007). Aristotle and Pedagogical Ethics. Paideusis,16(1), 17-28.

Kemmis, S. (2010). Research for praxis: Knowing doing. Pedagogy, Culture and Society, 18(1), 9-27.

Kemmis, S., \& Smith, T (2008). Praxis and praxis development. About this book. In S. Kemmis \& T. Smith (Eds.) Enabling practice. Challenges for education (pp. 314). Rotterdam: Sense.

Kemmis, S., \& Grootenboer, P. (2008). Situating praxis in practice: Practice architectures and the cultural, social and material conditions for practice. In S. Kemmis \& T. Smith (Eds.) Enabling practice. Challenges for education (pp. 37-64). Rotterdam: Sense.

Kemmis, S., \& McTaggart, R. (2000). Participatory Action Research. In N. Denzin \& Y. Lincoln (Ed.) Handbook of Qualitative Research. Lontoo: Sage, 567 - 606.

Kvale, S. (1996). Inter Views. An Introduction to Qualitative Research Interviewing. London: Sage.

Lane, D. A., \& Corrie, S. (2007). The Modern Scientist Practitioner. A guide to practice in psychology.

Lewin, B. C. W. B. C. E. de la C. (1993), the Reflective Practitioner in Teaching : Agenda Toward a Research. Teacher and Teacher Education, 9(4), 347-359. http://doi.org/10.1016/0742-051X(93)90002-X

Long, R. T. (2015). "What the Hell is Praxeology?". http://praxeology.net/praxeo.htm Retrieved June 2015.

Loughran, T., \& McDonald, B._(2014) Measuring Readability in Financial Disclosures. Journal of Finance, 69, 1643-1671

Marshall, E. (2010). Practice-Oriented Research. In Albert J. Mills, G. Durepos, \& E. Wiebe (Eds.), Encyclopedia of Case Study Research. (pp. 723-724). Thousand Oaks, CA: SAGE Publications, Inc. doi:10.4135/9781412957397.n266

Murray, L. (1992). What is practitioner based enquiry? Journal of In-Service Education, 18(3), 191-196. http://doi.org/10.1080/0305763920180309 
Naess, A., Christophersen, J.A., \& Kvalø, K. (1956). Democracy, ideology and objectivity studies in the semantics and cognitive analysis of ideological controversy. Oslo: Oslo University Press.

Nicolini, D. (2013). Practice, work and organization: an introduction. UK, Oxford: Oxford University Press.

Niglas, K. (2004). The Combined Use of Qualitative and Quantitative Methods in Educational Research. Dissertations in Social Sciences 8. Tallina: Tallinn Pedagogical University.

Patton, M. (2002). Qualitative Research and Evaluation Methods. (3. Ed.) London: SAGE.

Phillips, D.C. (2014). Encyclopedia of Educational Theory and Philosophy. London, SAGE. Plato (1925). Annotated English translation by Walter Rangeley Maitland Lamb, Plato in Twelve Volumes, 9. Cambridge, MA, Harvard University Press.

Popper, K.R. (1963). Conjectures and Refutations. London: Routledge Kegan Paul. Reason, P., \& Bradbury, H. (Eds.) (2007) The SAGE Handbook of Action Research. Participative Inquiry and Practice. 2nd Edition. London: Sage.

Röling, N., \& De Jong, F. (1998). Learning: shifting paradigms in education and extension studies. The Journal of Agricultural Education and Extension, 5(3), 143-161.

Ros, A., \& Vermeulen, M. (November, 2010). Standards of Practice-Based Research. Paper. Paper presented at the EAPRIL conference in Lisbon, 24-26.

Saugstad, T. (2005). Aristotle's Contribution to Scholastic and Non-Scholastic Learning Theories. Pedagogy, Culture and Society 13(3), 347-366.

Schaenen, I., Kohnen, A., Flinn, P., Saul, W., \& Zeni, J. (2012). "I” is for “insider":

Practitioner research in schools. International Journal of Action Research, 8(1), 68-101.http://doi.org/10.1688/1861-9916_IJAR_2012_01_Schaenen.

Shadish, W., Cook, T., \& Campbell, D. (2002). Experimental and Quasi-Experimental Designs. In Experimental and Quasi-Experimental Designs for Generalized Causal Inference. (pp. 171-206). http://doi.org/10.1093/obo/97801953896780053

Shaw, I., \& Lunt, N. (2012). Constructing practitioner research. Social Work Research, 36(3), 197-208. http://doi.org/10.1093/swr/svs013

Striker, G. (2002). What is a scientist-practitioner anyway? Journal of Clinical Psychology, 58(10), 1277-1283. http://doi.org/10.1002/jclp.10111

Sternberg, R. J. (1985). Beyond IQ: A Triarchic Theory of Intelligence. Cambridge: Cambridge University Press. 
Taylor, C. (1997). The Ethics of Authenticity. ( $7^{\text {th }}$ edition). Cambridge: Harvard University Press.

Van den Akker, J., Gravemeijer, K., McKenney, S., \& Nieveen, N. (2006). Educational Design Research. Milton Park: Routledge.

Van den Berg, N. (2016). Grenspraktijken, Opleiders en onderzoekers in ontwikkeling [Boundary crossing praxis, Teacher Educators and reseachers in development; Inaugural speech]. Wageningen: Stoas Vilentum Hogeschool.

Vanderlinde, R., \& Van Braak, J. (2010). The gap between educational research and practice: views of teachers, school leaders, intermediaries and researchers. British Educational Research Journal, 36(2), 299-316.

Wright, G. H. (1990). Explanation and Understanding. Ithaca, N.Y.: Cornell University Press. Zeller, N. (1995). Narrative strategies for case reports. In: J. A. Hatch \& R. Wisniewski (Eds.) Life history and narrative (pp. 75-88). London: Falmer. 